\title{
Unilateral versus Multilateral Strategies in the U.S. Exchange Rate Policy: Focusing on the State Centered Approach
}

Ajin Choi"

(Yonsei University)

\section{Contents}
I . Introduction
III. Explanations of Changes in the
П. Multisateral and Unilateral Strategies in the U.S. Exchange Rate Policy U.S. Exchange Rate Policy
IV. Conclusion

- Keywords: U.S. exchange rate policy, unilateral strategy, multilateral strategy, state centered approach, administration change, learning.

\section{【 ABSTRACT 】}

One of the features in the U.S. exchange rate policy is that unilateral and multilateral strategies alternate. This study explains these shifts based on administration change and learning process. The key finding in this study is that a new administration is more likely to adopt a unilateral strategy by neglecting the external effects of its policy and prioritizing domestic concerns while a seasoned administration is more likely to choose a multilateral strategy by learning international demands or constraints. This finding implies that the state centered approach is useful to understand U.S. foreign policy changes.

\footnotetext{
* I am grateful to Beth Simmons and Damon Coletta for many valuable suggestions. This research has been supported by the Center for International Studies, the Graduate School of International Studies, Yonsei University under the 6th faculty research grant (2003). I am alone responsible for any remaining errors.
} 


\section{I . Introduction}

Looking back over the past years of American foreign policy, we can find back and forth shifts between unilateralism and multilateralism. In particular, in order to achieve dollar depreciation or appreciation, the United States alternated between multilateral and unilateral strategies in its exchange rate policy. For example, in 1971, President Richard Nixon decided that international cooperation would be inadequate to achieve the needed currency realignment and thus adopted an extremely aggressive stance. This strategy attempted to accomplish the exchange rate realignment by demanding concessions from surplus countries, without having the United States make any serious concessions. The United States used this sort of unilateral strategy during 1971, 1976-1977 and 1980-1984. The resolution of the crisis by the unilateral approach often required cooperative international action. Robert Keohane uses the concept of multilateralism as "the practice of coordinating national policies in groups of three or more states."l) The breadth or diversity of multilateral arrangements across issue areas has recently increased. What makes a problem international is that it cannot be dealt with effectively within the national area. Its costs and benefits spill over into the external arena. These external effects are frequently so large that domestic goals cannot eventually be accomplished without coordinated multinational actions. Especially, in the international political economy area, this reality is often expressed as "global indivisibility." Under this condition, the United States had to adopt a multilateral strategy. Such an outcome occurred in 1972-1973, 1978-1979 and 1985-1986.

This study addresses a question of why the Unites States chose such different strategies over time in managing foreign exchange rate policy. I argue that new administrations tend to focus on domestic consideration and neglect international political economic forces, but these leaders eventually come to learn that the United States cannot achieve national interest solely based on a unilateral strategy and a multilateral approach can be a more effective alternative. In other words, the main hypothesis to be tested below is that new administrations are more likely to pursue a unilateral strategy, and later discovering that they are constrained by external factors, they pursue a multilateral solution. Throughout testing this argument, this study suggests that, compared to the systemic and social centered approaches, the state centered approach is more useful in explaining those shifts in the U.S. exchange rate policy.2)

1) Robert Keohane, "Multilateralism: An Agenda for Research," International Journal 45-3 (Autumn 1990), p.731. John Ruggie argues that what is a distinctive element of multilateralism is not merely that it coordinates national policies in groups of three or more states, which is something that other organization forms also do, but that is does so on the basis of certain principles of ordering relations among those states. See "Multilateralism; the Anatomy of an Institution," International Organization, 46-3 (Summer,1992), pp.569-74.

2) There are three theoretical approaches generally taken by scholars in this field. These are system-centered, state-centered and society-centered approaches. Each explanation has strengths 
The analysis below proceeds in three steps. The next section describes how the U.S. foreign exchange rate policy has changed from unilateral to multilateral strategies and from multilateral to unilateral strategies. The third section introduces possible different explanations for the causes of the back and forth shifts in the U.S. exchange rate policy during the 1970s and 1980s. Then, it singles out the most effective explanation and provides its theoretical mechanism and empirical evidence. In the conclusion section, I present the summary of key findings and their implications for international relations theory and practice.

\section{П. Multisateral and Unilateral Strategies in the U.S. Exchange Rate Policy}

Looking at the U.S. foreign exchange rate policy, there are back and forth movements from unilateralism to multilateralism within an administration, and from multilateralism to unilateralism between the administrations. ${ }^{3)}$ In August 1971, the Nixon administration set about devaluing the dollar by suspending gold convertibility unilaterally. Later, a more cooperative scenario emerged: the Smithsonian Agreement and the second devaluation of 1973. When the Carter Administration faced an overvalued dollar and deficits, it also responded primarily by pushing Japan and Germany to stimulate their economies. In mid 1978, when the decline of the dollar accelerated, however, the administration was forced to work out a cooperative defense of the dollar by intervening in the market and adopting more restrictive domestic policy. In the early 1980s, the Reagan administration unilaterally sought to sustain its domestic policy preferences unilaterally and this resulted in dollar over-valuation. After that, to correct the dollar's over-valuation, an even more cooperative approach to the monetary system and macro economic policy coordination was undertaken through the Plaza Accord. This agreement marked a reversal of the Reagan administration's handoff approach in its international monetary policy.

and weaknesses and no single explanation dominates this field. See John Ikenberry, David Lake and Michael Mastandanduno eds., The State and American Foreign Economic Policy (Ithaca, NY: Cornell University Press 1988).

3) I.M. Destler and Randall Henning describe the exchange rate policymaking in the Unites States during the 1980s as the cycle between neglect and activism. See Destler and Henning, Dollar Politics: Exchange Rate Policy Making in the United States (Washington D.C.: Institution for International Economics, 1989); Destler and Henning, "From Neglect to Activism: American Politics and 1985 Plaza Accord," Journal of Public Policy, 8-3 (September 1988); Henning, "Macroeconomic Diplomacy in the 1980s: Domestic Politics and International Conflict among the United States, Japan and Europe," Atlantic Paper 65 (London: Croom Helm, 1987); Benjamin Cohen, "An Explosion in the Kitchen? Economic Relations with other Advanced Industrial States," in Kenneth Oye, Robert Lieber, and Donald Rothchild eds., Eagle Defiant:United States Foreign Policy in the 1980s (Boston, MA: Little, Brown,1983); Fred Bergsten, "America's Unilateralism," in Bergsten, Etienne Davignon, and Isamu Miyazaski, Conditions for Partnership in International Economic Management, Report to the Trilateral Commission 32 (New York, NY; Trilateral Commission,1986). 


\section{The Nixon Administration}

Richard Nixon took office in January 1969 when the dollar was not under great market strain. International monetary policy was given a lower priority in the executive branch. Nixon and Henry Kissinger had a fairly clearly articulated world strategy, but they largely neglected economic issues in favor of traditional military political issues. For them, the most perilous challenge to American power was found in the relationships between the United States and the Soviet Union, or as they put it "the new administration, like its predecessors, saw in the great-power relationship the master key to world order."4) Therefore, they paid attention to international economic concerns only to the extent that such issues affected the success of their global military-political strategy. Furthermore, Nixon thought that devaluing the currency would invite negative domestic political effects and was reluctant to intervene in the economy.5) The Treasury Secretary David Kennedy stated that "it will be our purpose to maintain a strong dollar both at home and abroad," continually reaffirming that the dollar-gold price would not be changed.6) The President made no attempt to negotiate a parity adjustment with Japan or any other countries before August 151971.

By 1971 the deficit had deepened and Nixon's strategy of laissez faire, did not generate the expected positive effects. In August, no one believed that the external imbalance could be rectified at tolerable cost without a substantial exchange rate adjustment.7) Nixon decided to choose a unilateral diplomatic strategy. The administration embarked on the historic departure toward a new international monetary regime by unilaterally declaring the gold inconvertibility. By October, the dollar depreciated by approximately 7 percent from its 1970's level.

However, prolonged uncertainty was threatening business conditions and America's allies were strained as much as at any time since the end of the second world war. Nixon thought that the political costs of continuing the monetary stalemate would exceed the

4) Stanely Hoffman, Primacy or World Order: American Foreign Policy Since the Cold War (New York, NY: McGraw-Hill 1978), p.44.

5) John Odell, U.S. International Monetary Policy: Markets, Power and Ideas as Sources of Changes (Princeton, NJ: Princeton University Press 1982), pp.183-89.

6) Ibid., pp.190-91.

7) The Evidence of the consensus of this diagnosis is abundant. At mid summer, the Treasury, assuming no policy changes, concluded that the United States would have a $\$ 4$ billion deficit in the current account while the current account surplus of at least $\$ 9$ billion would be needed for overall balance (U.S., Congress, House, Committee on Foreign Affairs, The International Implications of the New Economic Policy: Hearings, 92nd Cong., 1st sess., 21 September 1971, p.82). The research staff of the IMF in early 1971 calculated the size of exchange rate changes that would be necessary to rectify fundamental disequilibria and forecasted that an average dollar depreciation of about 10 percent would be required (Margaret Garritsen de Vries, The International Monetary Fund 1966-1971: The System Under Stress, Washington, D.C.: IMF 1976, pp.537-38). During the summer, an OECD working paper also suggested that a certain form of parity change be necessary (New York Times, July 2 1971, p.45). 
economic gains. He, therefore, ordered a negotiating strategy and accepted a compromised agreement in December 1971. This was the Smithsonian Agreement. Nixon proclaimed this result as "the most significant monetary agreement in the history of the world."

A year later, the United States again achieved dollar devaluation by taking the lead in multilateral bargaining over new international monetary rules. The United States devalued the dollar and did not choose any options to support its currency based on market intervention or interest rate change. By March 1973, all major governments abandoned the regime of agreed par values and the Paris Conference inaugurated a new international monetary regime of managed floating exchange rates. Under this regime the intervention in currency markets was prohibited except in particular occasions when the fluctuations went too far.

The International Monetary Fund interim committee, meeting in Jamaica in January 1976, then put the final touches on the new regime that replaced the Bretton Woods arrangement. The constraints on states under the new regime were to collaborate with the Fund, to aim for orderly economic growth with reasonable price stability, to intervene in the exchange market if necessary to counter disorderly conditions, and to avoid manipulating exchange rates or the international monetary system in order to gain an unfair competitive advantage over other members.9) The new regime did not include any precise rules for adjustment obligations. The source of interstate conflict, therefore, remained and its solution left to both unilateral declaration and ad hoc bargaining.

\section{The Carter Administration}

The Carter Administration inherited a modestly overvalued dollar which produced merchandise deficits above $\$ 30$ billion in 1977. To accelerate out of the recession faster, the dollar needed to be depreciated. Early in 1978, when the Carter Administration stepped up its currency intervention primarily by pushing Japan and Germany to stimulate their economies to promote international equilibrium.

The Carter administration eventually came to the conclusion that dollar was too high relative to underlying market conditions and was generating unacceptable costs. At the Bonn Summit Meeting in 1978, the United States accepted adjustment, and Japan and West Germany agreed to expansionary measures. These efforts succeeded by mid 1978 in devaluing the dollar and thus pulling the United States out of recession.

However, the decline of the dollar accelerated too quickly leading to inflation and a growing lack of overall confidence in Administration's policies. Indeed, the dollar's exchange rate had sunk further than the administration believed necessary for payment equilibrium. In order to stop this decline, on November 1 1978, the U.S. government pledged massive currency intervention if necessary to encourage counter-speculation. To support this pledge, it assembled an additional pool of $\$ 28$ billion worth of foreign

8) New York Times, 19 December 1971, p.1

9) Odell, U.S. International Monetary Policy, p.329. 
currencies and credit lines from diverse sources. U.S. sales of gold, resumed in May 1978, were accelerated sharply, and the Federal Reserve boosted the discount rate another full percentage point. Treasury Secretary Michael Blumenthal made it clear that the United States was not pegging the dollar and the recent trends were clearly excessive. The November 1978 package was essentially another instance of "last-ditch" intervention and these actions promptly stopped the slide and by mid-1979 the dollar had climbed back nearly to its nominal external value of March 1973. The Federal Reserve had repaid its entire foreign currency swap debt by April 1979. On October 6 1979, the Federal Reserve announced a major change in domestic monetary policy in the direction of tighter money and credit conditions. ${ }^{10)}$ In response to the currency movements of 1978-1980, the Carter Treasury and the Federal Reserve considerably increased U.S. intervention to try to moderate exchange rate movements in either direction. When the dollar decline was severe, it adopted a cooperative policy to defend the dollar and a more restrictive domestic policy, particularly monetary policy as urged by other countries.

\section{The Reagan Administration}

In the early 1980s the Reagan Administration sought to sustain its domestic policy preferences unilaterally and resulted in dollar overvaluation. The first Reagan administration adopted tax cuts, increased defense spending, inflation reduction, and deregulatory economic programs. Reagan defended his domestic economic plan by saying that "the most important contribution any country can make to world development is to pursue sound economic at home."11) The mix of loose fiscal policy and tight monetary policy kept real interest rate high during his first administration. This policy resulted in tremendous upward pressure on the dollar and caused unprecedented pain for American producers of traded goods. Despite the sharp exchange movement and pressures from other countries, this administration kept to its strict non-intervention policy in foreign exchange rate.12)

Treasury Secretary Donald Regan and his Undersecretary for Monetary Affairs Beryl Sprinkel did not press for changes in the President's program to address the exchange rate consequences. Rather, they resisted the suggestion that monetary policy should be loosened to bring down the dollar. They did not push to lower the burgeoning budget deficits based on the exchange rate change. They even denied that any link existed at all among the budget deficit, the strong dollar and the growing trade deficit. They even announced that the Treasury would no longer intervene in the foreign exchange market to stabilize the dollar except on extraordinary occasions. Furthermore, Treasury leaders recognized that capital flows were important to sustaining the Reagan recovery and encouraged foreign investment into the United States, which Reagan , at that time, called as "investment capital of the world." The administration continuously pointed out the dollar's rise as the

10) Ibid., pp.327-40.

11) Ibid., pp.352-68.

12) I.M. Destler, "Reagan and the World: An 'Awesome Stubbornness'”, in Charles Jones ed., The Reagan Legacy (Chatham, NJ: Chatham House 1988). 
confidence in the Reagan economic program. By February 1985, when it reached its peak, the dollar rose by 67 percent from its 1980 average according to the IMF measure. 13) Four years of the first Reagan administration resulted in a rising dollar, high interest rates, current account deficit, protectionism in Congress, and complaints from trading partners.

The new Treasury leaders began to give a priority to dollar depreciation and stimulation of major surplus economies. "Suddenly Reagan's men are thinking that maybe the market isn't the best way to solve this problem."14) The Treasury leadership's ultimate success would depend on converting the promise of dollar depreciation into substantial gains on the trade front without generating a hard landing for the U.S. economy. In contrast to Regan and Sprinkel's laissez faire approach, Baker's new exchange rate policy required the cooperation of many actors. This effort resulted in the 1985 Plaza Accord. The G5 agreed that fundamental economic conditions had not been reflected fully in exchange markets and that exchange rate should play a role in adjusting external imbalances, and they concluded that the appreciation of the main non-dollar currencies against the dollar was desirable. 15) As a result, the dollar began to move downward. Multilaterally, by the Federal Reserve's measure, it had declined 12 percent on a trade-weighted basis since the Plaza Accord, and 25 percent since its February peak ${ }^{16)}$

Table 1 below summarizes the pattern of changes in the U.S. foreign exchange rate policy.

$\langle$ Table 1 1 Unilateral versus Multilateral Strategy in the U.S. Exchange Rate Policy

Strategy

\begin{tabular}{cll} 
& \multicolumn{1}{c}{ Unilateral } & \multicolumn{1}{c}{ Multilateral } \\
\hline \hline $\begin{array}{c}\text { Nixon Administration } \\
\cdot \quad \text { Earlier }\end{array}$ & $\begin{array}{l}\text { Nixon "benign neglect" } \\
\text { Nixon shock:gold inconvertibility }\end{array}$ & \\
$\cdot \quad$ Later & & $\begin{array}{l}\text { Smithonian Agreement } \\
\text { Second Dollar Devaluation } \\
\text { Jamaica Agreement }\end{array}$ \\
Carter Administration & & \\
$\cdot \quad$ Earlier & $\begin{array}{l}\text { Locomotive thesis } \\
\text { "talking down dollar" }\end{array}$ & \\
Reagan Administration & & Bonn Summit \\
$\cdot \quad$ Earlier & Non-intervention Policy & Dollar Support Program \\
$\cdot \quad$ Later & & Plaza Accord \\
\hline
\end{tabular}

13) Destler and Henning, Dollar Politics, pp.17-33.

14) Yoichi Funabashi, Managing the Dollar: From the Plaza to the Louvre (Washington, D.C.: Institute for International Economics 1988), p.12.

15) Henning and Destler, "From Neglect to Activism," p.322.

16) Destler and Henning, Dollar Politics, p.50. 


\section{Explanations of Changes in the U.S. Exchange Rate Policy}

\section{Theory: Adminstration Change and Learning Process}

In the past, the state traditionally has not been accepted as a significant variable in American political science circles. ${ }^{17)}$ There are, however, increasing interests in the role of state and the state has emerged as a crucial variable in the explanation of U.S. foreign economic policy. ${ }^{18)}$ This approach first examines how the institutional characteristics of states influence the policy process and particularly the ability of state officials to formulate and implement foreign economic policy. This state-centered approach to American foreign economic policy incorporated the concept of the state as an organizational structure or an actor. ${ }^{19)}$ Peter Katzenstein suggests that nation-states differ in the extent to which they are centralized, and in the range of policy instruments available to state officials in the conduct of foreign economic policy. They also differ in the degree of autonomy state officials enjoy relative to societal forces. Each different state can be placed along a continuum that range from "weak" to "strong." The United States is classified as a weak state.20) That is, the American state tends to be decentralized and fragmented along bureaucratic and institutional lines, and state officials lack the range of policy instruments available to their counterparts in stronger states. As a result, American state officials find it difficult to act purposefully and coherently, to realize their preferences in the face of significant opposition, or to manipulate their domestic environment.

There are doubts as to this status of the United States as a weak state. Some scholars argue that although the distinction between weak state and strong state may be appropriate for comparative purposes, it has a limited usefulness in the explaining a single case. ${ }^{21}$ ) A state's strength also varies with its capacity to perform the different tasks and across issue areas. Stephen Krasner argues that the U.S. state is weak in trade, while it is strong in international monetary policy. Judith Goldstein argues that even the weakness of the American state in foreign commercial policy has been exaggerated: she claims that the persistence of a liberal trade policy, despite domestic opposition to that stance "suggests

17) See Theda Skocpol, "Bringing the State Back In: Strategies of Analysis in Current Research," in Peter Evans, Dietrich Rueschemiyer, and Theda Skocpol eds., Bringing the State Back In (Cambridge, UK: Cambridge University Press 1985).

18) See Peter Katzenstein ed., Between Plenty and Power: Foreign Economic Policies of Advanced Industrial States (Madison, WI: University of Wisconsin Press 1978); John Zysman, Governments, Markets and Growth (Ithaca, NY: Cornell University Press 1983).

19) Ikenberry, Lake, and Mastanduno eds., The State and American Foreign Policy, p.10.

20) See Stephen Krasner, "United States Commercial and Monetary Policy" in Katzenstein ed., Between Plenty and Power.

21) See Ikenberry, Lake, and Mastanduno eds., The State and American Foreign Policy; On the other hand Helen Milner suggests that the weak state and strong state distinction may be problematic in the comparative context as well. See Milner, Resisting Protectionism: Global Iindustries and the Politics of International Trade (Princeton, NJ: University of Princeton Press 1988). 
an ability on the part of the U.S. government to retain its autonomy from society."22) Even arguing that a weak state should be no more pervasive in both the U.S. trade and monetary policies, Joanne Gowa explains that the power of actors varies as the public character of political goods varies. ${ }^{23)}$ Overall, this approach asserts that states matter more and can serve as an important independent variable in explaining the U.S. foreign economic policy. Furthermore, an increasing interest in states enhances understanding both system-centered and the society-centered approaches because it is the state that translate the constraints and opportunities of the international system, and it is the state officials and institutions that can shape the role of sectors or interest groups in economic foreign policy.

If the state centered approach is employed, the next question is how the state under the same administration realizes that a unilateral strategy is limited, national interests are redefined, and the state eventually comes to adopt a multilateral strategy by responding to international constraints. In order to answer these questions I incorporate the concept of "learning" into this analysis. ${ }^{24)}$ States can change beliefs about policy goals and optimal means to achieve by learning about their environment. The strategy change of the U.S. foreign exchange rate policy can be, therefore, explained by the change of administrations and their learning skills to adjust to the external environment as a result of the gradual accumulation of experience over time.

Table 2 below shows the theoretical mechanisms on how the two strategies alternate.

〈Table 2 > Process of Change of Strategic Choices Within and Between the Administrations

Earlier Administration Later Administration
$\begin{aligned} & \text { Process of } \\ & \text { Changes in } \\ & \text { Strategies }\end{aligned}$
Unilateral-<LEARNING $>$-Multilatera l-<CHANGE OF-Unilateral
ADMINISISTRATION $>$

22) It is generally argued that the U.S. state is weak in trade while it is strong in international monetary policy. See Krasner, "United States Commercial and Monetary Policy" in Katzenstein, Between Power and Plenty. Judith Goldstein argues that the weakness of the American state in foreign commercial policy has been exaggerated: the persistence of a liberal trade policy, despite domestic opposition to that stance, she maintains, suggests an ability on the part of the U.S. government to retain its autonomy form society. That autonomy is a result of the ideological adherence of central decision makers to the tenets of free trade. See Goldstein, "A Domestic Explanation for Regime Formation and Maintenance: Liberal Trade Policy in the U.S." The Annual American Political Science Meeting (1984), pp.13-4.

23) Joanne Gowa, "Public Goods and Political Institutions: Trade and Monetary Policy Processes in the United States" International Organization 42-1 (Winter 1988).

24) For the impacts of learning on foreign policy, see Joseph Nye, "Nuclear Leaming and U.S.-Soviet Security Regimes," International Organization $41-3$ (Summer 1987); Jack Levy, "Learning and Foreign Policy: Sweeping a Conceptual Minefield," International Organization 48-2 (Spring 1994); Dan Reiter, "Leaming, Realism, and Alliances: The Weight of the Shadow of the Past," World Politics 46-4 (July 1994). 


\section{Alternative Explanations and their Limits}

We have observed the pattern of changes in the U.S. foreign exchange rate policy strategy and reviewed the theoretical mechanisms to explain these changes. In this section, two altemative explanations for the changes in the U.S. foreign exchange rate policy and their weaknesses will be presented.

\section{1) Pressure from the Systemic Level}

One of the altemative explanations lies in the systemic level pressure, namely the structure or distribution of power in the international system, which sets broad limits on the possibilities for international monetary arrangements and the outcomes. Changes in that power structure can partly explain the shifts in the U.S. foreign exchange rate policy as the Nixon administration decisions to suspend gold convertibility of the dollar, to depreciate and then to float the currency. ${ }^{25}$ )

One of the systemic features of the evolving international economy that underlies the pattern of policy fluctuation is the increasing impacts of external events and economic interdependence on the U. S. economy: for example, the share of exports in the American GNP rose 250 percent from the 1950s to the 1980s; Over 40 percent of the U.S. farm acreage produced for export in the early 1980s, and during the same period of time one quarter of all manufactured goods were sold abroad; the oil shocks had a drastic impact on the whole American economy; the improvement in its trade balance accounted for three quarters of total U.S. economic growth in 1980; the subsequent deterioration in that trade balance was responsible for more than half the recession in 1981-1982 and cut domestic growth in half during the second half of 1984 and 1985; the huge inflow of foreign capital permitted the boom of 1983 and early 1984 without renewed inflation or crowding out; and the supply-side economics turned out to be that the rest of the world was willing to supply the needed finance for America's twin deficits. ${ }^{26)}$ These figures show that as the interdependence is increasing, the economic sovereignty is decreasing even for the United States, and American policymakers can generate huge problems by ignoring the rest of world or by trying to reshape it in their own way.

Another important structural feature is the declining ability of the United States to force its will on the rest of the world. This point implies that the United States needs to move to from a purely national American standpoint to a pluralistic approach to manage its economy effectively and can be shown by the fact that the unilateral strategy of

25) Robert Keohane and Joseph Nye, Power and Interdependence: World Politics in Transition (Boston, MA: Little Brown 1977); Benjamin Cohen, Organizing the World's Money: The Political Economy of International Monetary System (New York, NY: Basic Books 1977); Odell, U.S. International Monetary Policy; Barry Eichengreen, "Hegemonic Stability Theories of the International Monetary System" in Richard Cooper ed., Can Nations Agree? Issues in International Economic Cooperation (Washington D.C.: Brookings Institute 1989).

26) Bergsten, "Conditions for Partnership in International Economic Management," pp.9-10. 
1971,1976-77 and 1981-84 could not be sustained for long and was followed by the multilateral strategy of 1972-73, 1978-79 and 1985-86. Furthermore, major countries were often reluctant to change their fundamental economic policies in ways that would permit them to be truly cooperative with the American adjustment. For example, Germany and Japan were reluctant to accept adequate revaluations in 1971, to locomote in 1977, and to deregulate capital flow in the early 1980's. Such unwillingness increased the possibility for the United States to adopt a multilateral strategy.

The third structural feature is the presence and efficacy of the international economic institutions. There are now simply no international rules which significantly affect the conduct of national policy. The IMF largely abdicated any such responsibility after the move to floating exchange rates; its "multinational surveillance" has had no visible impact. Meaningful macroeconomic and monetary cooperation is left completely to ad hoc efforts. The efforts such as the Bonn summit in1978 and the Plaza Agreement of the G5 in 1985 have been successful. But the world is left with neither functioning rules nor effective institutions in the core issues of global economic management. This implies that the United States is encouraged to choose a unilateral initiative to pursue its economic policy goals. Fred Bergsten suggests that the creation of effective international arrangements along the lines of target zones for currency relationships or macroeconomic collaboration based on "objective indicators" is thus essential to promote more stable policies in the United States. This arrangements should be more flexible and symmetrical efforts than those in the past such as Bretton Woods regime. But, they need to be firm enough to prod all countries including the United States to consider the international ramifications of their actions on both themselves and the rest of world.27)

Although the pressures from the international systemic level existed and exerted influence, it does not seem that the United States shifted its foreign exchange rate policy fundamentally in response to external conditions. For example, though the U.S. economic situation in 1981 was widely seen as intolerable and unacceptable, the international economic balance was not an apparent constraint on the Reagan economic agenda or performance. When it became clear in 1982 that the economy was experiencing the worst recession of the postwar period, they did not change their basic policy. The explanation depending on the international system and structure is, thus, not so convincing when the fluctuations in the U.S. exchange rate policy are examined over time. In addition, in the post war period the global power structure has changed only gradually, but the U.S. exchange rate policy often changed suddenly from unilateral to multilateral and vice versa. To explain these policy changes, we, therefore, need to incorporate the national level politics into the analysis.

\section{2) Pressures from Society}

National level politics are twofold: a society centered explanation and a state centered

27) Ibid., p.11. 
explanation. First, in regard to the society centered approach, John Odell maintains that interest-group pressures were only a part of the background of the U.S. external monetary policy. During the Nixon era, no interest groups organized public or even private campaign to change or influence U.S. international liquidity or exchange rate policy. Labor unions were not particularly active on behalf of reserve creation, nor did bankers particularly oppose the Special Drawing Right scheme. Banks and corporations did lobby only against capital controls and these efforts contributed to the relaxation of capital controls. Rather, public pressure on Nixon was easing rather than pressing him toward further devaluation or initiative for negotiation for the policy changes. The conspicuous interest group activity to shift foreign economic policy during this period was on behalf of general import protection. 28$)$

Furthermore, according to Yoichi Funabashi, the Plaza strategy was the political manifestation of the Reagan administration's decision to succumb to reality. It was designed by the new Baker Treasury to fulfill three main objectives: first, to combat protectionism in Congress; second, to maintain world economic growth by stimulating domestic demand in Japan and West Germany; third, to ease the burden of debt service of the United State s.29) Obviously, there were pressures from private sectors which stood to gain from dollar depreciation and these pressures certainly contributed to growing sentiment in the Congress and among the public against strong dollar and thus to policy changes. But, this can not explain all of the changes of U.S. exchange rate policy and changes in strategy. For example, private groups' pressure is only in one direction. We can not find any evidence that the private sector which could have gained from dollar appreciation pressed the government to act in support of strong dollar in early $1980 \mathrm{~s}$. It is, therefore, hard to assert that exchange rate policy changes are the result of sectoral conflicts.

\section{The Main Explanation}

Finally, we will move to the state-centered approach to explain the shifts in the strategy of U.S. foreign exchange rate policy. When exchange rate misalignment and external deficit are present, exchange rate policy becomes an important domestic political issue. It was the state that has drove exchange rate policy change with unilateral action or multilateral action trying to persuade foreign governments to adjust. The interplays of institution, process, and actor can explain the timing and scope of policy change accepting or denying social pressures and interpreting the cure for external constraints differently. Gowa argues that the Nixon administration's policy in the dying days of the postwar monetary system was not generated by a particular group interest within U.S. society. Instead, it was generated largely by state officials: what prevented the Nixon administration from attempting to preserve the Bretton Woods System was the images of the domestic and

28) Odell, U.S. International Monetary Policy, pp.312-25.

29) Funabashi, Managing the Dollar, p.4. 
international systems shared by its officials. ${ }^{30}$ )

How state officials changed from a unilateral strategy to a multilateral strategy can be explained based on the process of learning. Recognizing the openness of national economies, the costs of sustained currency misalignments, and necessity for adjustment, the government moves from a unilateral strategy to a multilateral bargaining position. For example, whereas the first Reagan administration preferred a unilateral hands-off international economic policy by arguing that it best serves the world economy by best serving itself, the administration later learned that the unilateral strategy was limited and that a multilateral strategy was necessary for the United States and the world economy. As the government became aware external constraints, the administration's foreign economic objectives shifted from protecting the domestic program and reducing inflation to maintaining the world and U.S. economic recovery with a multilateral strategy. Whereas as a keynote of administration's international economic policy Reagan addressed in 1981 that "the most important contribution any country can make to world development is to pursue sound economic policies at home."31) Treasury Secretary Baker stated in 1986 that more and "more, government today realize that to great extent their domestic prosperity hinges on the condition of the international economy...the time is long past when the United States could, in setting domestic policies, relegate external considerations to a second order of importance."32) The example of Reagan administration is not the only case of changes in U.S. policy since the 1970s. Whenever the current account deficit and overvaluation of dollar became unsustainable, the administration in charge at the time had to admit that international factors should be taken into consideration in shaping U.S. exchange rate policy.

The result of this learning process is followed by the replacement of key economic policymakers in the same administration. During the Nixon administration, John Connally, the Treasury Secretary, called for closing the gold window and thought that without unilateral treatment, other governments would be more frustrated by the adjustment. In May 1972, Nixon appointed George Shultz to replace him. Shultz began to signify the changes preferring to joint decision making with allies. Shultz brought back an inclination toward multilateral compromise rather than unilateral coercive diplomacy. ${ }^{33)}$ During the Carter administration, Carter replaced Treasury Secretary Blumenthal with William Miller. When it recognized the need for intervention to try to moderate exchange rate movement in either direction, Miller and Volker, Chairman of Federal Reserve System made more of an effort

30) Joanne Gowa, "State Power, State Policy: Explaining the Decision to Close the Gold Window," Politics and Society, 13-1 (1984).

31) Washington Post (September 30, 1991), p.1.

32) James Baker, "'Remarks to the 1986 International Monetary Conference, Boston, Massachussetts," in Henning, Macroeconomic Diplomacy in the 1980s, Atlantic Paper 65,1987, pp.49-50. Henning explains that there are three phases of the U.S. international monetary policy-neglect, conflict, and mutual adjustment.

33) See Odell, U.S. International Monetary Policy. 
at multilateral decision making then their predecessors. During the Reagan administration Donald Regan, the Treasury Secretary tried not to do anything to make the dollar's value different from the unique rate determined by domestic and foreign macroeconomic and private economic force. He believed that private agents were able to provide stability at least as well as the government and argued that sterilized intervention would risk public funds, discourage private participation, and could not affect the exchange rate on a lasting basis. ${ }^{34)}$ This policy produced dollar appreciation. Despite the pressure from society and other countries, the Treasury did not change the exchange rate policy. In a stark contrast, when new Treasury Secretary James Baker took office in 1985, this new leadership thought that prospects for foreign cooperation were favorable, and finally generated the Plaza Accord. ${ }^{35)}$ These three cases illustrate that learning external and internal constraints, newly appointed officials produced a drastic departure from the strategy of the previous ones thus resulting in policy changes from unilateral to multilateral within the administration.

The next question is why each administration repeats the pattern of change and does not try to follow the former administration. In other word, the question is why new administration prefers a unilateral strategy. For example, the first Reagan administration pursued a policy of neglect of the exchange rate of the dollar. This was a fundamentally unilateral policy and a reversal of the strong multilateral interventionism pursued by the Carter administration. The Cater administration also tried to pursue a different strategy than the Nixon-Ford administration.

Observing U.S. economic policy, new administrations pay attention to the domestic outcomes of its foreign economic policy. The United States, like most countries, prefers naturally to pursue its domestic economic objectives as autonomously as possible. Owing to its size and power, new administration which lacks intemational experience is more likely to design foreign economic policy to serve the domestic program. The learning experience by the past administration is lost to a new administration.

We have explained that the changes of exchange rate policy is represented by the change of the administrations and their learning about international constraints. A problem in this argument is that learning process is hard to test. Therefore the following question can be raised; whether this change in the U.S. exchange rate policy represents learning or the mere adaption to changing circumstance. Changes in international constraint played an important role in changes in exchange rate policy strategy. They are not, however, enough to explain shifts in its exchange rate policy strategy. There is a lag between international constraints and strategy changes. This lag can be explained by the changes in administrations and by concept of learning. International constraints cannot directly affect strategy changes in its exchange rate policy. But, they have an impact on strategy changes through the changes of political official's perception and their learning processes. In regard to the U.S. foreign exchange policy, a new President was disposed to leave such matters subordinated to domestic priority. During the earlier period of each administration, Nixon,

34) Destler and Henning, Dollar Politics, pp.17-32.

35) Henning and Destler, "From Neglect to Activism," pp.323-28. 
Carter and Reagan pursued a unilateral strategy in managing its exchange rate policy and were not receptive to suggestions that they take the lead in negotiating multilaterally international economic reforms. Later, as their own unilateral policy could not be compatible with those of rest of the world, their earlier beliefs were changed and they learned that their objectives could not be achieved unless other major governments acted together. They thus began to adopt multilateral strategies. But this learning did not survive in the new administration because of natural preference for unilateral strategies by a new administration prioritizing domestic consideration.

\section{Conclusion}

One of the features in the past U.S. exchange rate policy was that unilateral and multilateral strategies alternate. This study has explained these shifts in the U.S. foreign policy strategies based on the administration change and learning process. The key finding in this analysis is that a new administration is more likely to adopt a unilateral strategy by neglecting the external effects of its policy and prioritizing domestic concems while a seasoned administration is more likely to choose a multilateral strategy by learning international constraints.

The three U.S. administration cases regarding their exchange rate policy confirm this finding: In 1971 the U.S. trade balance recorded an external deficit for the first time. The Nixon administration concluded that international cooperation would be inadequate and pronounced the dollar devaluation unilaterally by suspending gold convertibility in August. Later, as it learned that its economy could not improved without coordinating with foreign governments, a more cooperative strategy emerged. When the Carter administration was faced with an overvalued dollar and trade deficit, it at first responded primarily by pushing Japan and Germany to stimulate their economies. Later, this administration realized that it could not defend the value of dollar without the adjustment of U.S. economy and pursued a more cooperative strategy suggested by other countries. The early Reagan administration unilaterally sought to appreciate the dollar. As this policy generated serious complaints from domestic constituents as well as foreign countries, the administration changed toward a multilateral approach to correct the over-valuation of dollar.

The finding in this study has the following implications for international relations theory and practice. By focusing on the change of the administration and its learning process, this study has suggested that the state centered approach is more useful to understand U.S. foreign policy changes than the systemic and society centered approaches. Furthermore, the finding in this study challenges the recent finding in this field that the early administration is more likely to make concessions to external demands or challenges. Finally, this study suggests that however powerful the state is, it is difficult to continue to achieve its foreign policy goals or successes without adjusting to external demands or constraints in the closely interdependent world. 


\section{References}

Bergsten, Fred, “America's Unilateralism," In Fred Bergsten, Etienne Davignon and

Isamu Miyazaski, Conditions for Partnership in International Economic Management, Report to the Trilateral Commission 32, (New York, NY: Trilateral Commission), 1986.

Cohen, Benjamin, Organizing the World's Market: The Political Economy of International Monetary System, (New York, NY: Basic Books), 1977.

, "An Explosion in the Kitchen? Economic Relations with other Advanced Industrial States," in Kenneth Oye, Robert Lieber, and Donald Rothchild eds., Eagle Defiant, (Boston, MA: Little, Brown), 1983.

Destler, I. M., "Reagan and the World: An Awesome Stubbornness," in Charles Jones ed., The Reagan Legacy (chatham, NJ: Chatham House), 1988.

Destler, I. M. and Randall Henning, Dollar Politics: Exchange Rate Policy Making in the United States, (Washington D.C.: Institution for International Economics), 1989.

, "From Neglect to Activism: American Politics and 1985 Plaza Accord," Journal of Public Policy, 8-3 (September, 1988).

Eichengreeen, Barry, "Hegemony Stability Theories of the International Monetary System" in Richard Cooper ed., Can Nations Agree? Issues in International Economic Cooperation, (Washington D.C.: Brookings Institute), 1989.

Funabashi, Yoichi, Managing the Dollar: From the Plaza to the Louvre, (Washington, D.C.: Institute for International Economics), 1988.

Goldstein, Judith, "A Domestic Explanation for Regime Formation and Maintenance," presented at the American Political Science Association Meeting, 1984.

Gowa, Joanne, "Public Goods and Political Institutions," International Organization, 42-1 (Winter, 1988).

, "State Power, State Policy," Politics and Society, 13-1 (1984).

Henning, Randall, "Macroeconomic Diplomacy in the 1980s: Domestic Politics and International Conflict among the United States, Japan and Europe," Atlantic Paper, 65 (London, UK: Croom Helm), 1987.

Hoffman, Stanely, Primacy or World Order: American Foreign Policy since the Cold War, (New York, NY: McGraw-Hill), 1978.

Ikenberry, John, David Lake, and Michael Mastandanduno eds., The State and American Foreign Economic Policy, (Ithaca, NY: Cornell University Press), 1988.

Katzenstein, Peter, Between Power and Plenty: Foreign Economic Policies of Advanced Industrial States, (Madison, WI: University of Wisconsin Press), 1978.

Keohane, Robert, "Multilateralism: An Agenda for Research," International Journal, 45 (Autumn, 1990).

Kransner, Stephen, "United States Commercial and Monetary Policy," in Peter Katzenstein, Between Power and Plenty: Foreign Economic Policies of Advanced Industrial States, (Madison, WI: University of Wisconsin Press), 1978.

Levy, Jack, "Leaming and Foreign Policy: Sweeping a Conceptual Minefield," International Organization, 48-2 (Spring, 1994).

Milner, Helen, Resisting the Protectionism: Global Industries and the Politics of International Trade, (Princeton, NJ: Princeton University Press), 1988. 
Nye, Joseph, "Nuclear Learning and U.S.-Soviet Security Regimes," International Organization, 41-3 (Summer, 1987).

Nye, Joseph and Robert Keohane, Power and Interdependence: The World Politics in Transition, (Boston, MA: Little Brown), 1977.

Odell, John, U.S. International Monetary Policy: Markets, Power and Ideas as Sources of Changes, (Princeton, NJ: Princeton University Press), 1982.

Reiter, Dan, "Learning, Realism, and Alliances: The Weight of the Shadow of the Past," World Politics, 46-4 (July, 1994).

Ruggie, John, "Multilaterlaism: the Anatomy of an Institution." International Organization, 46-3 (Summer, 1992).

Skocpol, Theda, "Bringing the State Back In" in Peter Evans, Dietrich Rueschemiyer, and Theda Skocpol eds., Bringing the State Back In, (Cambridge, UK: Cambridge University Press), 1985.

Zysman, John, Government, Markets and Growth, (Ithaca, NY: Comell University Press), 1983. 